\title{
Synthesis of 2,4-dihydroxychalcone Derivatives as Potential Antidepressant Effect
}

Authors

Affiliations

\section{L.-P. Guan' ${ }^{1}$, D.-H. Zhao' ${ }^{2}$ Y. Chang1, 3, Z.-S. Wen ${ }^{1}$, L.-M. Tang1, F.-F. Huang}

${ }^{1}$ Food and Pharmacy College, Zhejiang Ocean University, Zhejiang, Zhoushan, China 2 Jilin Medical College, Jilin City, Jilin, China

${ }^{3}$ College of Pharmacy, Yanbian University, Yanji, Jilin, China
Key words

- 2,4-dihydroxychalcone derivatives

synthesis

- antidepressant activity

- 5-Hydroxytryptophan

- yohimbine received 28.09.2012 accepted 26.11.2012

\section{Bibliography}

DOI http://dx.doi.org/

10.1055/s-0032-1333229

Published online:

January 24, 2013

Drug Res 2013;

63: 46-51

(c) Georg Thieme Verlag KG Stuttgart · New York ISSN 2194-9379

\section{Correspondence}

\section{L.-P. Guan}

Food and Pharmacy College Zhejiang Ocean University

Qixiangtai Road

316004 Zhoushan

China

Tel.: + 86/580/2554 536

Fax: + 86/580/2554 781

glp730@yahoo.com.cn

\section{D.-H. Zhao}

Jilin Medical College

No 5 jilin Street

132013 jilin

China

Tel.: + 86/432/64560025

Fax: $+86 / 432 / 64560301$

zdh1027@sina.com

\section{Abstract}

$\nabla$

In this study, twelve 2,4-dihydroxychalcone derivatives were synthesized and evaluated for antidepressant activities using the forced swimming test (FST). The pharmacological test showed that 6 compounds significantly reduced the immobility times in the FST at a dose of $10 \mathrm{mg} / \mathrm{kg}$, indicative of antidepressant activity. Among the derivatives, compounds

\section{Introduction}

$\nabla$

Depression is one of the most prevalent psychopathologies. Symptoms of depression include lowered mood, and reduced interest and pleasure. It is predicted by the World Health Organization to become the second leading cause of diseaserelated disability by the year 2020 [1,2]. Despite the introduction of tricyclic and monoamine oxidase inhibitors (MAOIs) and selective serotonin reuptake inhibitors (SSRIs) to treat depression, the therapeutic results have not been satisfactory. Only one-third of afflicted individuals have remission and the subjects always suffer from the side effects, such as anxiety, sleep disturbance, weight gain, and sexual dysfunction [3-5]. Therefore, there is an unmet need for new antidepressants. Chalcones (trans-1,3-diphenyl-2-propen-1-ones) are biogenetic precursors of flavonoids [6]. Their chemical structure consists of open-chain flavonoids in which 2 aromatic rings are joined by a 3 -carbon $\alpha, \beta$-unsaturated carbonyl system. They present a broad spectrum of biological activities, such as anti-tumor, anti-oxidation, anti-inflammatory, antiviral, antilipidemic, and antidepressant activities [7-12].

Previously, our research team found that isoliquiritigenin and butein ( $\bullet$ Fig. 1) showed antidepressant-like effects in the forced swimming test (FST; $p<0.05$ and $p<0.01$, respectively) in mice, designated $3 \mathrm{~d}$ and $3 \mathrm{~h}$ exhibited the best antidepressant activity, with reduced immobility time by $32.05 \%$ and $34.33 \%$, respectively. In the 5-hydroxytryptophan-induced head-twitch test and yohimbine-induced mortality test, compounds $3 \mathrm{~d}$ and $3 \mathrm{~h}$ increased head-twitch and increased the mortality rate. The mechanisms of the antidepressant effects of compounds $3 \mathrm{~d}$ and $3 \mathrm{~h}$ may be related with the 5-HTP and NE nervous system. but had weaker activity than the reference drug fluoxetine $(p<0.001)$ [13]. To obtain new compounds with better antidepressant effects, in this paper, we tried to chemically modify chalcone to improve its bioavailability, therefore a series of 5,7-dihydroxychalcone derivatives were designed and synthesized. The antidepressant activity of the synthesized compounds were also determined by using Porsolt's behavioral despair (Forced Swimming Test: FST) and Steru's behavioral despair (Tail Suspension Test: TST) [14,15]. Because the monoaminergic system is one of the most important targets in the pathophysiology and therapies for depression $[16,17]$, in this study we used 2 behavioural models to investigate the possible monoaminergic antidepressant effects of 2 compounds, designated $3 \mathrm{~d}$ and $3 \mathrm{~h}$.

\section{Materials and Methods \\ $\nabla$ \\ Chemistry}

Melting points were determined in open capillary tubes and were uncorrected. IR spectra were recorded (in KBr) on a FT-IR1730 (Bruker, Switzerland), ${ }^{1} \mathrm{H}$-NMR and ${ }^{13} \mathrm{C}$-NMR spectras were measured on an AV-300 (Bruker, Switzerland), and all chemical shifts were given in ppm relative to tetramethysilane. Mass spectra were measured on an HP1100LC (Agilent Technologies, 
<smiles>CC(C)(C)OC(=O)/C=C/c1ccc(O)cc1/C=C/c1ccc(O)c(O)c1</smiles>

Fig. 1 Structure of Isoliquiritigenin and Butein.

USA). Elemental analysis(CHN) were performed on a Perkin Elmer 204Q CHN or a Heraeus CHN Rapid Analyzer. The major chemicals were purchased from Aldrich Chemical Corporation. All other chemicals were the analytical grade.

\section{Synthesis of 2'-hydroxy-3-bromo-4' -}

methoxymethoxychalcone(2d)

To a stirred solution of $15 \% \mathrm{KOH}$ cooled to $0^{\circ} \mathrm{C}$ in an ice bath was added dropwise a solution of 2-hydroxy-4-methoxymethoxyactetophenone $(2.0 \mathrm{mmol})$ and 3-bromobenzaldehyde $(4.0 \mathrm{~m}$ $\mathrm{mol}$ ) in ethanol under nitrogen. The reaction mixture was kept at room for $8 \mathrm{~h}$. The mixture was poured into the ice-water, adjusted to $\mathrm{pH} \mathrm{2-3}$ with $1 \mathrm{M} \mathrm{HCl}$, and the extracted with ethyl acetate. The organic layer was washed with water and saturated brine, dried over anhydrous $\mathrm{Na}_{2} \mathrm{SO}_{4}[18]$. After removing solvents, the product was recrystallized from ethanol. The yellow solid was obtained. Yield $83 \%$; ${ }^{1} \mathrm{H}$ NMR $\left(300 \mathrm{MHz}, \mathrm{CDCl}_{3}, \mathrm{TMS}\right)$ : $\delta 3.46\left(\mathrm{~s}, 3 \mathrm{H}, \mathrm{OCH}_{3}\right), 5.34\left(\mathrm{~s}, 2 \mathrm{H}, \mathrm{CH}_{2}\right), 6.37-7.54(\mathrm{~m}, 6 \mathrm{H}, \mathrm{Ar}-\mathrm{H})$. $7.69\left(\mathrm{~d}, 1 \mathrm{H}, J=15.6 \mathrm{~Hz}, \mathrm{H}_{\alpha}\right), 7.88\left(\mathrm{~d}, 1 \mathrm{H}, J=15.6 \mathrm{~Hz}, \mathrm{H}_{\beta}\right), 12.78$ (s, $\mathrm{H},-\mathrm{OH})$; IR (KBr) $\mathrm{cm}^{-1}$ : 3364, 1658; MS m/z: 363(M+1).

\section{General procedure for the preparation of compounds(3a-I)}

In a round-bottomed flask, to a stirred solution of chalcones 2a-1 $(0.25 \mathrm{mmol})$ in methanol was added dropwise $3 \mathrm{M} \mathrm{HCl}$, the mixture was refluxed for $30 \mathrm{~min}$. The solvents were removed under the reduced pressure and diluted with water, and extracted with ethyl acetate. The organic layer was washed with water and brine, dried over anhydrous $\mathrm{Na}_{2} \mathrm{SO}_{4}$. After concentration under reduced pressure, the resultant was recrystallized from ethanol[19]. The yield, melting point and spectral data of part compounds are given below.

2',4'-dihydroxychalcone 3a: Yield 82.5\%; m.p. 80.2-80.4 ${ }^{\circ} \mathrm{C}$; ${ }^{1} \mathrm{H}$ NMR $\left(300 \mathrm{MHz}\right.$, DMSO- $d_{6}$, TMS): $\delta 6.40-7.47\left(\mathrm{~m}, 3 \mathrm{H},-\mathrm{C}_{6} \mathrm{H}_{3}\right)$, $7.68(\mathrm{~d}, 1 \mathrm{H}, J=15 \mathrm{~Hz},=\mathrm{CH}), 7.21-7.39\left(\mathrm{~m}, 5 \mathrm{H},-\mathrm{C}_{6} \mathrm{H}_{5}\right), 7.78(\mathrm{~d}, 1 \mathrm{H}$, $J=15 \mathrm{~Hz},=\mathrm{CH}), 10.54(\mathrm{~s}, \mathrm{H},-\mathrm{OH}), 12.57(\mathrm{~s}, \mathrm{H},-\mathrm{OH}) ;{ }^{13} \mathrm{C}-\mathrm{NMR}$ (DMSO- $\left.d_{6}, 300 \mathrm{MHz}\right): 103.4,106.4,114.8,117.1,124.8,127.7$, 128.6, 131.3, 132.6, 134.8, 136.2, 141.2, 154.3, 166.5, 183.4; IR (KBr) $\mathrm{cm}^{-1}$ : 3318, 1643; Anal. Calcd. for $\mathrm{C}_{15} \mathrm{H}_{12} \mathrm{O}_{3}: \mathrm{C}, 74.99 ; \mathrm{H}$, 5.03; O, 19.98. Found: C, 74.86; H, 4.92; O, 19.87. MS: $\mathrm{m} / \mathrm{z}[\mathrm{M}+1]$ 241.

3-Fluoro-2',4'-dihydroxychalcone 3b: Yield 65\%; m.p. $176^{\circ} \mathrm{C}$; ${ }^{1} \mathrm{H}$ NMR $\left(300 \mathrm{MHz}\right.$, DMSO- $d_{6}$, TMS): $\delta 6.42-7.52\left(\mathrm{~m}, 3 \mathrm{H},-\mathrm{C}_{6} \mathrm{H}_{3}\right)$, $7.50(\mathrm{~d}, 1 \mathrm{H}, J=15 \mathrm{~Hz},=\mathrm{CH}), 7.03-7.32\left(\mathrm{~m}, 4 \mathrm{H},-\mathrm{C}_{6} \mathrm{H}_{4}\right), 7.92(\mathrm{~d}, 1 \mathrm{H}$, $J=15 \mathrm{~Hz},=\mathrm{CH}), 10.78(\mathrm{~s}, \mathrm{H},-\mathrm{OH}), 12.54(\mathrm{~s}, \mathrm{H},-\mathrm{OH}) ;{ }^{13} \mathrm{C}-\mathrm{NMR}$ (DMSO- $d_{6}, 300 \mathrm{MHz}$ ): 103.7, 108.4, 115.5, 116.6, 123.7, 127.7, 128.6, 130.9, 133.5, 133.8, 135.5, 142.8, 162.3, 164.7, 185.7; IR (KBr) $\mathrm{cm}^{-1}$ : 3324, 1628; Anal. Calcd. for $\mathrm{C}_{15} \mathrm{H}_{11} \mathrm{FO}_{3}$ : C, 69.76; $\mathrm{H}$,
4.29; O, 18.59. Found: C, 69.68; H, 4.20; O, 18.48. MS: m/z [M+1] 259.

3-Chloro-2',4'-dihydroxychalcone 3c: Yield 80.6\%; m.p. $166.5-166.7^{\circ} \mathrm{C}$; ${ }^{1} \mathrm{H}$ NMR $\left(300 \mathrm{MHz}\right.$, DMSO- $d_{6}$, TMS): $\delta 6.36-$ $7.57\left(\mathrm{~m}, 3 \mathrm{H},-\mathrm{C}_{6} \mathrm{H}_{3}\right), 7.59(\mathrm{~d}, 1 \mathrm{H}, \mathrm{J}=15 \mathrm{~Hz},=\mathrm{CH}), 7.21-7.35(\mathrm{~m}, 4 \mathrm{H}$, $\left.-\mathrm{C}_{6} \mathrm{H}_{4}\right), 7.88(\mathrm{~d}, 1 \mathrm{H}, J=15 \mathrm{~Hz},=\mathrm{CH}), 11.12(\mathrm{~s}, \mathrm{H},-\mathrm{OH}), 13.09(\mathrm{~s}, \mathrm{H}$, -OH); ${ }^{13} \mathrm{C}-\mathrm{NMR}$ (DMSO- $\mathrm{d}_{6}, 300 \mathrm{MHz}$ ): 104.6, 108.9, 117.6, 122.6, 124.7, 127.6, 128.8, 130.5, 132.6, 133.6, 134.5, 142.8, 157.3, 166.7, 187.7; IR (KBr) $\mathrm{cm}^{-1}$ : 3314, 1630; Anal. Calcd. for $\mathrm{C}_{15} \mathrm{H}_{11} \mathrm{ClO}_{3}$ : C, 65.58; $\mathrm{H}, 4.04 ;$ O, 17.47. Found: C, 65.46; H, 4.11; O, 17.34. MS: $\mathrm{m} / \mathrm{z}[\mathrm{M}+1] 275$.

3-Bromo-2',4'-dihydroxychalcone 3d: Yield 73\%; m.p. 127$129^{\circ} \mathrm{C} ;{ }^{1} \mathrm{H}$ NMR $\left(300 \mathrm{MHz}, \mathrm{DMSO}-\mathrm{d}_{6}\right.$, TMS): $\delta 6.45-7.54(\mathrm{~m}, 3 \mathrm{H}$, $\left.-\mathrm{C}_{6} \mathrm{H}_{3}\right), 7.53(\mathrm{~d}, 1 \mathrm{H}, J=15 \mathrm{~Hz},=\mathrm{CH}), 7.18-7.43\left(\mathrm{~m}, 4 \mathrm{H},-\mathrm{C}_{6} \mathrm{H}_{4}\right)$, 7.95(d, $1 \mathrm{H}, J=15 \mathrm{~Hz},=\mathrm{CH}), 9.78(\mathrm{~s}, \mathrm{H},-\mathrm{OH}), 11.78(\mathrm{~s}, \mathrm{H},-\mathrm{OH})$; ${ }^{13}$ C-NMR (DMSO-d 6 , 300 MHz): 102.7, 108.6, 114.6, 117.6, 123.3, 127.5, 128.1, 130.4, 133.2, 133.6, 135.7, 141.8, 161.4, 165.7, 186.7; $\mathrm{IR}(\mathrm{KBr}) \mathrm{cm}^{-1}$ : 3329, 1629; Anal. Calcd. for $\mathrm{C}_{15} \mathrm{H}_{11} \mathrm{BrO}_{3}$ : C, 56.45; H, 3.47; O, 15.04. Found: C, 56.32; H, 3.31; O, 15.11. MS: $\mathrm{m} / \mathrm{z}[\mathrm{M}+1] 319$.

4-Fluoro-2',4'-dihydroxychalcone 3e: Yield 64\%; m.p. 76.3$77^{\circ} \mathrm{C} ;{ }^{1} \mathrm{H}$ NMR (300 MHz, DMSO-d $\mathrm{d}_{6}$, TMS): $\delta 6.39-7.54(\mathrm{~m}, 3 \mathrm{H}$, $\left.-\mathrm{C}_{6} \mathrm{H}_{3}\right), 7.49(\mathrm{~d}, 1 \mathrm{H}, J=15 \mathrm{~Hz},=\mathrm{CH}), 6.98-7.29\left(\mathrm{~m}, 4 \mathrm{H},-\mathrm{C}_{6} \mathrm{H}_{4}\right)$, 7.96(d, $1 \mathrm{H}, J=15 \mathrm{~Hz},=\mathrm{CH}), 10.23(\mathrm{~s}, \mathrm{H},-\mathrm{OH}), 12.76(\mathrm{~s}, \mathrm{H},-\mathrm{OH})$; ${ }^{13}$ C-NMR (DMSO- $\left.d_{6}, 300 \mathrm{MHz}\right): 101.7,108.8,114.5,118.6,122.7$, 126.9, 128.3, 129.9, 131.5, 132.9, 134.8, 141.8, 158.3, 163.8, 187.7; IR (KBr) $\mathrm{cm}^{-1}: 3324,1628$; Anal. Calcd. for $\mathrm{C}_{15} \mathrm{H}_{11} \mathrm{FO}_{3}: \mathrm{C}$, 69.76; H, 4.29; O, 18.59. Found: C, 69.60; H, 4.18; O, 18.45. MS: $\mathrm{m} / \mathrm{z}[\mathrm{M}+1] 259$.

4-Chloro-2',4'-dihydroxychalcone 3f: Yield 81\%; m.p. 186.1$186.9^{\circ} \mathrm{C}$ (see in literature[20])

4-Bromo-2',4'-dihydroxychalcone 3g: Yield 74\%; m.p. 187$188^{\circ} \mathrm{C} ;{ }^{1} \mathrm{H}$ NMR(300 MHz, DMSO- $d_{6}$, TMS): $\delta 6.42-7.58(\mathrm{~m}, 3 \mathrm{H}$, $\left.-\mathrm{C}_{6} \mathrm{H}_{3}\right), 7.55(\mathrm{~d}, 1 \mathrm{H}, J=15 \mathrm{~Hz},=\mathrm{CH}), 7.13-7.35\left(\mathrm{~m}, 4 \mathrm{H},-\mathrm{C}_{6} \mathrm{H}_{4}\right)$, 7.97(d, $1 \mathrm{H}, J=15 \mathrm{~Hz},=\mathrm{CH}), 9.98(\mathrm{~s}, \mathrm{H},-\mathrm{OH}), 12.65(\mathrm{~s}, \mathrm{H},-\mathrm{OH})$; ${ }^{13}$ C-NMR (DMSO- $d_{6}, 300 \mathrm{MHz}$ ): $102.8,108.9,115.8,117.6,124.7$, 128.7, 129.5, 132.7, 133.4, 134.7, 136.5, 141.8, 158.2, 165.6, 188.1; $\mathrm{IR}(\mathrm{KBr}) \mathrm{cm}^{-1}: 3330,1631$; Anal. Calcd. for $\mathrm{C}_{15} \mathrm{H}_{11} \mathrm{BrO}_{3}: \mathrm{C}$, 56.45; H, 3.47; O, 15.04. Found: C, 56.35; H, 3.34; O, 15.14. MS: $\mathrm{m} / \mathrm{z}[\mathrm{M}+1] 319$.

2,6-Dichloro-2',4'-'-dihydroxychalcone 3h: Yield 68.7\%; m.p. 99.2-99.9 ${ }^{\circ}$; ${ }^{1} \mathrm{H}$ NMR (300 MHz, DMSO- $\left.d_{6}, \mathrm{TMS}\right): \delta 6.38-7.48(\mathrm{~m}$, $\left.3 \mathrm{H},-\mathrm{C}_{6} \mathrm{H}_{3}\right), 7.45(\mathrm{~d}, 1 \mathrm{H}, J=15 \mathrm{~Hz},=\mathrm{CH}), 7.11-7.28\left(\mathrm{~m}, 3 \mathrm{H},-\mathrm{C}_{6} \mathrm{H}_{3}\right)$, $8.13(\mathrm{~d}, 1 \mathrm{H}, J=15 \mathrm{~Hz},=\mathrm{CH}), 10.82(\mathrm{~s}, \mathrm{H},-\mathrm{OH}), 13.13(\mathrm{~s}, \mathrm{H},-\mathrm{OH})$; ${ }^{13}$ C-NMR (DMSO- $d_{6}, 300 \mathrm{MHz}$ ): 102.9, 109.4, 117.3, 124.1, 127.2, 129.3, 132.4, 134.1, 135.2, 135.8, 141.4, 143.6, 158.5, 165.3, 187.8; IR (KBr) cm ${ }^{-1}$ : 3329, 1628 ; Anal. Calcd. for $\mathrm{C}_{15} \mathrm{H}_{10} \mathrm{Cl}_{2} \mathrm{O}_{3}$ : C, 58.28; H, 3.26; O, 15.53. Found: C, 58.17; H, 3.20; O, 15.46. MS: $\mathrm{m} / \mathrm{z}[\mathrm{M}+1] 309$.

4-Methyl-2',4'-dihydroxychalcone 3i: Yield 84\%; m.p. 103$104^{\circ} \mathrm{C} ;{ }^{1} \mathrm{H}$ NMR (300 MHz, DMSO- $d_{6}$, TMS): $\delta 2.36\left(\mathrm{~s}, 3 \mathrm{H}, \mathrm{CH}_{3}\right)$, $6.40-7.51\left(\mathrm{~m}, 3 \mathrm{H},-\mathrm{C}_{6} \mathrm{H}_{3}\right), 7.46(\mathrm{~d}, 1 \mathrm{H}, J=15 \mathrm{~Hz},=\mathrm{CH}), 7.01-$ $7.22\left(\mathrm{~m}, 4 \mathrm{H},-\mathrm{C}_{6} \mathrm{H}_{4}\right), 7.96(\mathrm{~d}, 1 \mathrm{H}, J=15 \mathrm{~Hz},=\mathrm{CH}), 10.65(\mathrm{~s}, \mathrm{H},-\mathrm{OH})$, 12.72 (s, H, $-\mathrm{OH}$ ); ${ }^{13} \mathrm{C}-\mathrm{NMR}$ (DMSO- $\mathrm{d}_{6}, 300 \mathrm{MHz}$ ): 20.4, 102.6, 108.6, 116.6, 120.4, 123.0, 126.5, 127.2, 129.4, 131.3, 132.5, 
133.3, 134.2, 140.8, 157.3, 166.7, 187.9; IR (KBr) $\mathrm{cm}^{-1}: 3326$, 1629; Anal. Calcd. for $\mathrm{C}_{16} \mathrm{H}_{14} \mathrm{O}_{3}$ : C, 75.57; H, 5.55; O, 18.88 . Found: C, 75.45; H, 5.41; O, 18.76. MS: m/z [M+1]255.

4-dimethylamino-2',4'-dihydroxychalcone 3j: Yield 79\%; m.p. $192^{\circ} \mathrm{C}$ (see in literature[20])

1-(2,4-dihydroxyphenyl)-3-(furan-2-yl)prop-2-en-1-one 3k: Yield 68.6\%; m.p. $117-119{ }^{\circ} \mathrm{C}$; ${ }^{1} \mathrm{H}$ NMR (300 MHz, DMSO$d_{6}$, TMS $): \delta 6.40-7.56\left(\mathrm{~m}, 3 \mathrm{H},-\mathrm{C}_{6} \mathrm{H}_{3}\right), 7.55(\mathrm{~d}, 1 \mathrm{H}, \mathrm{J}=15 \mathrm{~Hz},=\mathrm{CH})$, 6.75-7.84(m, 3H, -furan), 7.95(d, $1 \mathrm{H}, J=15 \mathrm{~Hz},=\mathrm{CH}), 10.12(\mathrm{~s}, \mathrm{H}$, -OH), 12.76 (s, H, -OH); ${ }^{13} \mathrm{C}-\mathrm{NMR}$ (DMSO-d, $300 \mathrm{MHz}$ ): 103.3, $108.9,111.5,112.6,117.3,128.9,142.7,145.8,155.6,159.6$, 166.2, 187.7; IR (KBr) $\mathrm{cm}^{-1}$ : 3328, 1623; Anal. Calcd. for $\mathrm{C}_{13} \mathrm{H}_{10} \mathrm{O}_{4}$ : C, 67.82; H, 4.38; O, 27.80. Found: C, 67.76; H, 4.29; O, 27.75. MS: $\mathrm{m} / \mathrm{z}[\mathrm{M}+1] 231$.

1-(2,4-dihydroxyphenyl)-3-(naphthalen-1-yl)prop-2-en-1-one 3l: Yield 84.7\%; m.p. $191-192{ }^{\circ} \mathrm{C} ;{ }^{1} \mathrm{H}$ NMR (300 MHz, DMSO- $d_{6}$, TMS): $\delta 6.42-7.59\left(\mathrm{~m}, 3 \mathrm{H},-\mathrm{C}_{6} \mathrm{H}_{3}\right), 7.48(\mathrm{~d}, 1 \mathrm{H}, J=15 \mathrm{~Hz},=\mathrm{CH})$, 7.23-7.73(m, 7H, -naphthalen), 7.97( d, $1 \mathrm{H}, J=15 \mathrm{~Hz},=\mathrm{CH}), 10.32$ (s, H, -OH), 12.78 (s, H, -OH); ${ }^{13} \mathrm{C}-\mathrm{NMR}$ (DMSO-d, $300 \mathrm{MHz}$ ): 103.2 , 108.5, 116.8, 120.6, 123.4, 125.4, 126.8, 127.4, 128.8, 131.5, 132.6, 133.5, 135.7, 136.8, 142.7, 161.3, 166.8, 188.6; IR $(\mathrm{KBr}) \mathrm{cm}^{-1}$ : 3331, 1629; Anal. Calcd. for $\mathrm{C}_{19} \mathrm{H}_{14} \mathrm{O}_{3}: \mathrm{C}, 78.61 ; \mathrm{H}$, 4.86; O, 16.53. Found: C, 78.57; H, 4.78; O, 16.43. MS: m/z [M+1] 291.

\section{Pharmacology}

Animals

Male Kunming mice weighing 20-24g (Laboratory of Animal Research, College of Pharmacy, Yanbian University, Yanji, Jilin, China) were used in this study. Mice were housed collectively in groups of 10 in polycarbonate cages. They were maintained on a $12 \mathrm{~h}$ light/dark cycle in a temperature controlled $\left(22-25^{\circ} \mathrm{C}\right)$ laboratory. Food and water were available ad libitum. All procedures used in the present study were in accordance with the Guide for the Care and Use of Laboratory Animals as adapted by the NIH (Bethesda, MD, USA). All efforts were made to minimize animal suffering and to reduce the number of animals used.

\section{Forced swimming test (FST)}

The FST used was the same as described in detail elsewhere Porsolt $[14,15]$. The synthesized compounds were screened for their antidepressant activity. Local breed, male Kunming mice (20-24 g) were used in the forced swimming test under standard conditions with free access to food and water. They were housed in groups of 6 , In the experiment, mice were assigned into different groups ( $\mathrm{n}=10$ for each group). The synthesized compounds $(10 \mathrm{mg} / \mathrm{kg})$ and fluoxetine as a reference antidepressant drug $(10 \mathrm{mg} / \mathrm{kg}$ ) were dissolved in DMSO through injected intraperitoneally (ip) in a standard volume of $0.05 \mathrm{~mL} / 20 \mathrm{~g}$ body weight, $30 \mathrm{~min}$ prior to the test. Briefly, mice were individually placed in a glass cylinder $(25 \mathrm{~cm}$ in height, $10 \mathrm{~cm}$ in diameter filled with $10-\mathrm{cm}$ high of water $22-25^{\circ} \mathrm{C}$ ). Each mouse was given a 6 -min swimming test, and the duration of immobility was observed and measured during the final 4-min interval of the test. All test swim sessions were recorded by a video camera positioned directly above the cylinder. 2 competent observers, who were unaware of the treatment each mouse had received, scored the videotapes. Immobility period was regarded as the time spent by the mouse floating in the water without struggling and mak- ing only those movements necessary to keep its head above the water. Following swimming sessions, they were then towel dried and returned to their housing condition. The animals were used only once in this test. All FSTs were performed between 12:00a.m. and 19:00 p.m.

\section{Tail suspension test (TST)}

The TST was conducted as previously described [21]. Briefly, the synthesized compounds $(10 \mathrm{mg} / \mathrm{kg}$ ) and fluoxetine as a reference antidepressant drug $(10 \mathrm{mg} / \mathrm{kg})$ were dissolved in DMSO through injected intraperitoneally (ip) in a standard volume of $0.05 \mathrm{~mL} / 20 \mathrm{~g}$ body weight, $30 \mathrm{~min}$ prior to the test. Then, mice were individually suspended by tail with clamp $(2 \mathrm{~cm}$ from the tip of the end $)$ in a box $(25 \times 25 \times 30 \mathrm{~cm})$ with the head $5 \mathrm{~cm}$ to the bottom. Testing was carried out in a darkened room with minimal background noise. All animals were suspended for total $6 \mathrm{~min}$, and the duration of immobility was observed and measured during the final 4-min interval of the test. All test sessions were recorded by a video camera positioned directly above the box. 2 competent observers blind to treatment scored the videotapes. Mice consider immobile only when they hung passively and completely motionless. The animals were used only once in this test. All TSTs were performed between 12:00a.m. and 16:00 p.m.

\section{Hydroxytryptophan(5-HTP) induced mouse head-twitch} test

To investigate whether the serotonergic system was involved in the antidepressant-like effect of compounds $3 \mathrm{~d}$ and $3 \mathrm{~h}$, we performed a 5-HTP induced head-twitch test $[22,23]$. Totally 24 male Kunming (20-25g) mice were randomly chosen and divided into 3 groups normal control group, group of compounds $3 \mathrm{~d}$ and $3 \mathrm{~h}$, and positive control (fluoxetine). Mice were administered a i.p. injection with compounds $3 \mathrm{~d}$ and $3 \mathrm{~h}$ (30 mg/ $\mathrm{kg}$ ), fluoxetine (30 mg/kg) $60 \mathrm{~min}$ before 5 -HTP ( $100 \mathrm{mg} / \mathrm{kg}$, i.p.). Immediately after the second injection, mice were placed into plastic cages. $10 \mathrm{~min}$ later, the cumulative number of head twitches (rapid movements of the head with little or no involvement of the trunk) was recorded for $6 \mathrm{~min}$. All test sessions were recorded by a video camera. The animals were used only once in this test, the head-twitch tests were performed between 10:00 a.m. and 12:00.

\section{Yohimbine toxicity potentiation test}

To trveal whether the noradrenergic system is involved in the antidepressant-like effect of the compounds $3 \mathrm{~d}$ and $3 \mathrm{~h}$, the yohimbine toxicity potentiation test was performed [22].Totally 24 male Kunming (20-25g) mice were randomly chosen and divided into 3 groups: normal control group, group of the compounds $3 \mathrm{~d}$ and $3 \mathrm{~h}$, and positive control group (clomipramine), clomipramine ( $30 \mathrm{mg} / \mathrm{kg}$ )(i.p.), $1 \mathrm{~h}$ prior to yohimbine administration $(20 \mathrm{mg} / \mathrm{kg}$, s.c.). The number of dead mice was calculated during a $20 \mathrm{~h}$ period after the injection of yohimbine.

\section{Statistical analysis}

Results are expressed as mean \pm S.E.M.; $n$ represents the number of animals. Data obtained from pharmacological experiments were analyzed with 1-way analysis of variance (ANOVA) followed by Dunnet's post hoc test, using Pharmacologic Calculation System Version 4.1.(Microcomputer Specialists). A p-value of less than 0.05 was considered statistically significant. 


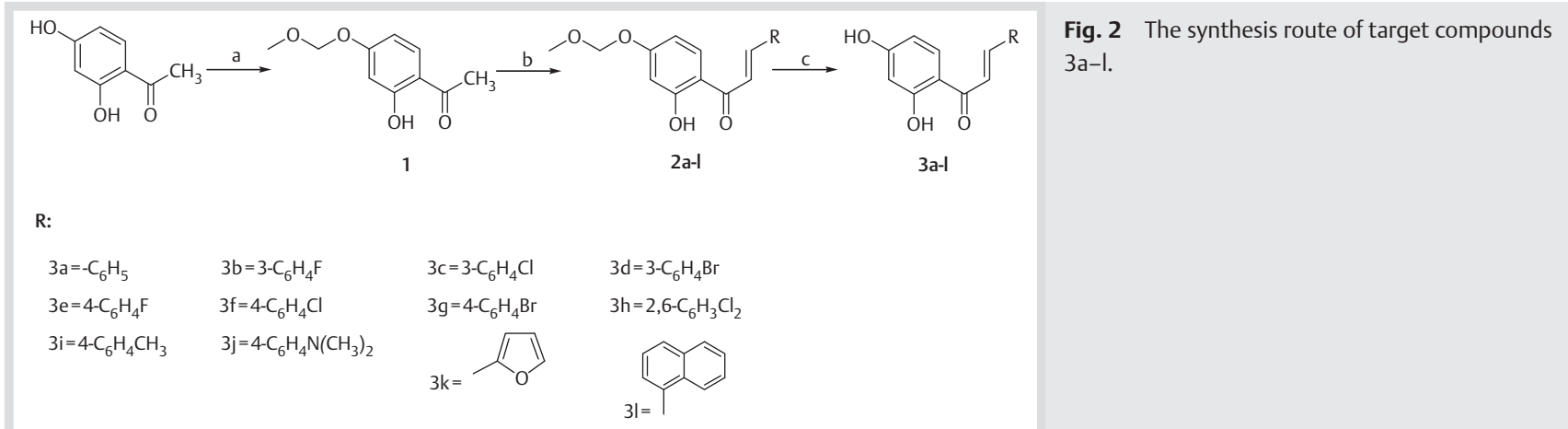

Reagents and conditions: (a) $\mathrm{ClCH}_{2} \mathrm{OCH}_{3}, \mathrm{~K}_{2} \mathrm{CO}_{3}$, acetone, $0^{\circ} \mathrm{C}$ to r.t.; (b) aromatic aldehyde, $15 \% \mathrm{KOH}$, $\mathrm{EtOH}$; (c) $3 \mathrm{M} \mathrm{HCl}, \mathrm{MeOH}$, reflux.

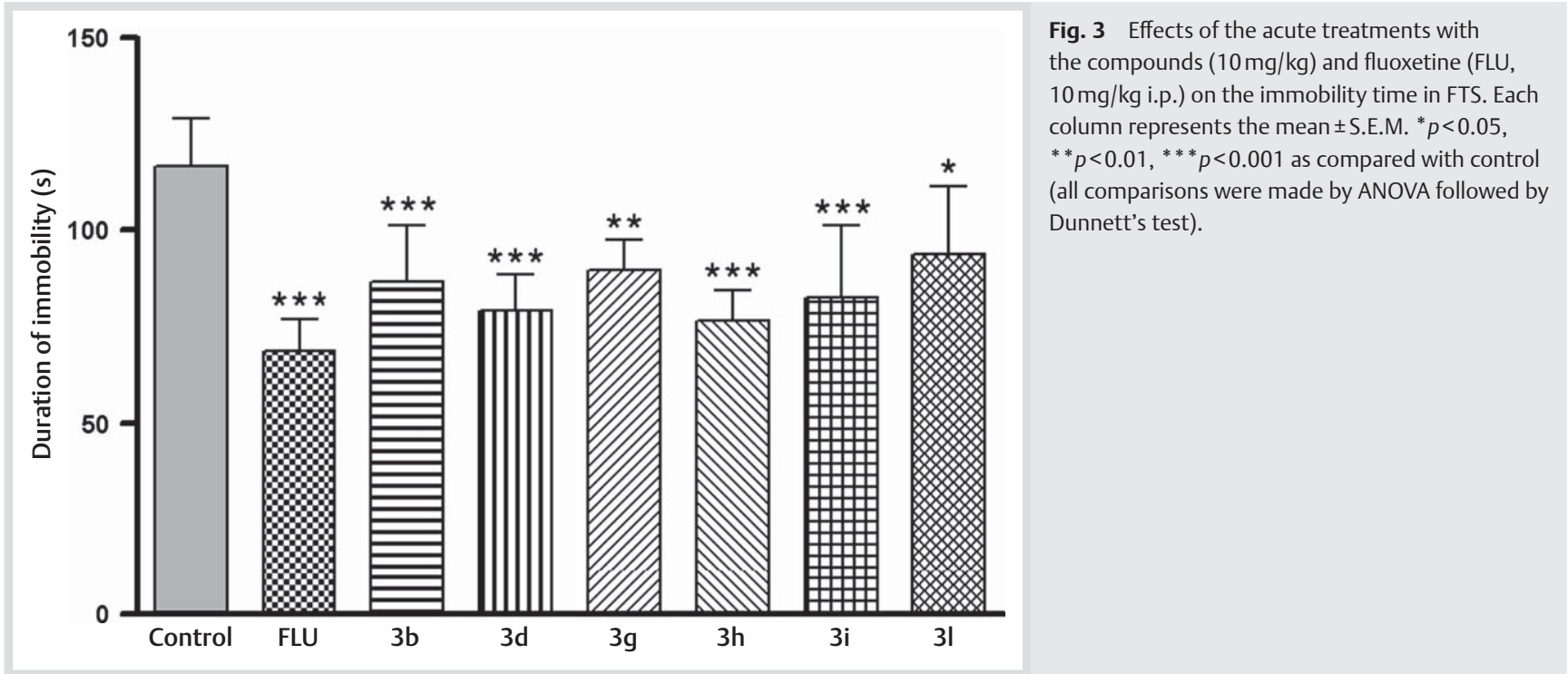

\section{Results and Discussion}

$\nabla$

\section{Chemistry}

The target compounds 3a-l were synthesized as outlined $\bullet$ Fig. 2. Compound 1 was prepared as reported previously in the literature [13]. The intermediates 2a-l were prepared by the Claisen-Schmidt condensation reaction from compound 1 , with appropriate aromatic aldehydes, protected as chloromethyl methyl ether in EtOH at room temperature in high yields $[19,24]$. Then 2,4-dihydroxychalcone derivatives (3a-l) were obtained with $3 \mathrm{M} \mathrm{HCl}$ in methanol in good yield [25] ( 0 Fig. 2). The structures of these compounds were confirmed by IR, ${ }^{1} \mathrm{H}-\mathrm{NMR}$, or ${ }^{13} \mathrm{C}-\mathrm{NMR}$, mass spectrometry, and elementary analysis.

\section{Pharmacological evaluations}

The forced swimming test (FST) and the tail suspension test (TST) were designed by Porsolt et al. and Steru L et al. as a primary screening test for antidepressants. FST and TST are behavioral tests used to predict the efficacy of antidepressant treatments $[14,15]$. They are two of the best models for this purpose for several reasons. They are used effectively in predicting the activity of a wide variety of antidepressants, and are lowcost, fast and reliable models to test potential antidepressant treatments with strong predictive validity. The immobility time observed in the test reflects a state of lowered mood or hopelessness in the animal. Thus, these animal models are the most widely used tools for preclinical screening of putative antidepressant agents, and have good predictive value for antidepressant potency in humans $[26,27]$.

In the present study, 12 compounds were described for their antidepressant activities in mice using the FST. The pharmacological tests revealed that 6 compounds showed good antidepressant activities. Acute treatment with compounds $3 \mathrm{~b}, 3 \mathrm{~d}, 3 \mathrm{~g}$, $3 \mathrm{~h}, 3 \mathrm{i}$, and 31 significantly promoted a decrease in the immobility time in the FST at $10 \mathrm{mg} / \mathrm{kg}$, as depicted in 8 Fig. 3 (control $=116.7 \pm 12.3 ; 3 b=86.7 \pm 14.5 ; 3 d=79.3 \pm 9.2 ; 3 g=89.8 \pm 7.8$; $3 \mathrm{~h}=76.7 \pm 7.9 ; \quad 3 \mathrm{i}=82.5 \pm 18.7 ; \quad 3 \mathrm{l}=93.8 \pm 17.7 ; \quad$ fluoxet ine $=68.6 \pm 8.3$ ). The immobility time of mice treated with compounds $3 \mathrm{a}, 3 \mathrm{c}, 3 \mathrm{e}, 3 \mathrm{f}, 3 \mathrm{j}$, and $3 \mathrm{k}$ did not statistically differ from control values, as shown in 0 Fig. 4 (control $=116.7 \pm 12.3$; $3 a=96.3 \pm 31.2 ; 3 c=95.2 \pm 12.6 ; 3 e=111.7 \pm 10.5 ; 3 f=105.8 \pm 11.6$; $3 \mathrm{j}=97.5 \pm 15.6 ; 3 \mathrm{k}=98.5 \pm 6.5$; fluoxetine $=68.6 \pm 8.3)$. Among, 2 compounds, 3d (3-bromo-2',4'-dihydrox-ychalcone) and $3 \mathrm{~h}$ (2,6-dichloro-2', $4^{\prime}$-dihydroxychalcone) were found to be the most potent, and significantly reduced the duration of immobility times at the $10 \mathrm{mg} / \mathrm{kg}$ dose level when compared with the control $(p<0.001)$.

Generally, the activity of an organic compound is markedly increased after the introduction of a halogen atom. Therefore, in this paper some halogen-substituted derivatives were designed and synthesized. Analyzing the antidepressant activity of the synthesized compounds 3a-l, the following SAR was derived. 


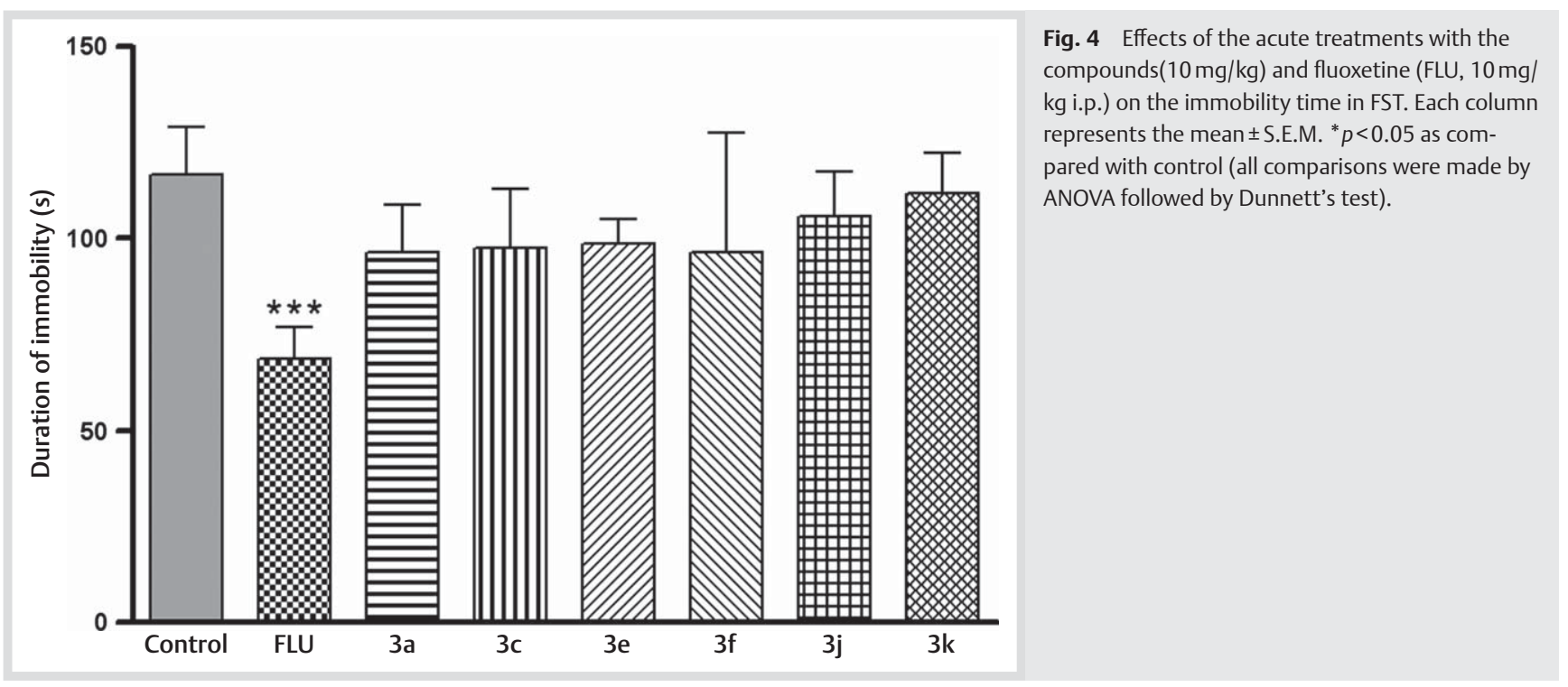

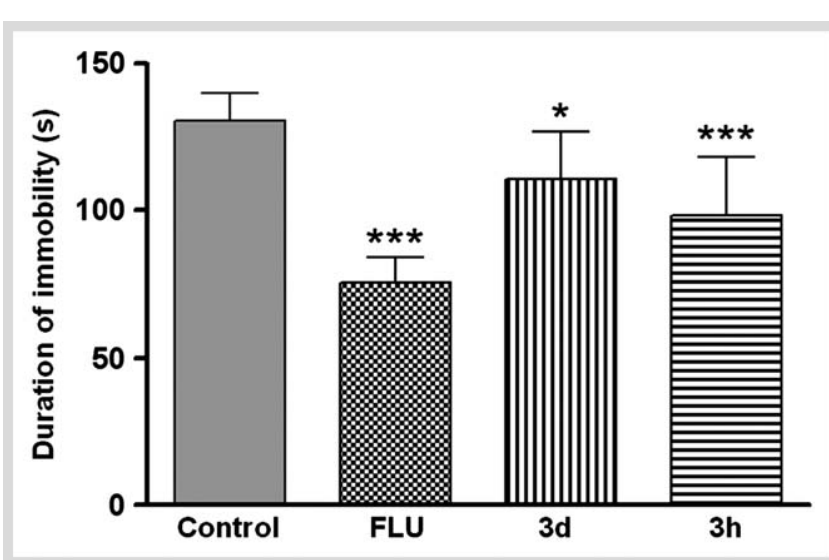

Fig. 5 Immobility time of the compounds $3 \mathrm{~d}$ and $3 \mathrm{~h}$ in mouse TST after intraperitoneal administration in mice (i.p.) at $10 \mathrm{mg} / \mathrm{kg}$. Data are expressed as mean \pm S.E.M. $(n=10)$. Statistical analysis of the data was carried out by one-way analysis of variance followed by the t-test. ${ }^{*} p<0.05$, ${ }^{* * *} p<0.001$ vs. control.

Table 1 Effects of compound 3d, $3 \mathrm{~h}$ and fluoxetine on the number of 5-HTP induced head twitches in mice.

\begin{tabular}{|c|c|c|c|}
\hline Compounds & Dose (mg/kg) & $\begin{array}{l}\text { 5-HTP (mg/ } \\
\mathrm{kg})\end{array}$ & $\begin{array}{l}\text { Number of } \\
\text { head twitchs }\end{array}$ \\
\hline $3 d$ & 30 & 100 & $36.5 \pm 12.4^{*}$ \\
\hline $3 \mathrm{~h}$ & 30 & 100 & $28.7 \pm 10.2^{*}$ \\
\hline Fluoxetine & 30 & 100 & $42.7 \pm 11.3^{* *}$ \\
\hline Control & - & 100 & $15.7 \pm 5.2$ \\
\hline
\end{tabular}

The halogen-substituted derivatives ( $3 b-h$ ), compounds except $3 c$, 3 e, and $3 \mathrm{f}$ displayed antidepressant activity in the FST. The $\mathrm{Br}$ atom contributed more to antidepressant activity than the F and $\mathrm{Cl}$ atoms. The rank order of activity of the halogen-substituted compounds was $\mathrm{Br}>\mathrm{F}>\mathrm{Cl}$. Among the compounds, $3 \mathrm{~d}$ and $3 \mathrm{~h}$ showed the most antidepressant activity, with reduced the immobility time by $32.05 \%$ and $34.33 \%$, respectively, at $10 \mathrm{mg} /$ $\mathrm{kg}$. Next, the position of the halogen substituted on the phenyl ring greatly influenced the antidepressant activity, compared with compounds with different $\mathrm{Cl}$-substituted positions on the phenyl ring. Their rank order of activity was $2,6-\mathrm{Cl}_{2}>3-\mathrm{Cl}>4-\mathrm{Cl}$. Regarding the electron-donor group contributing to the antidepressant activity ( $\odot$ Fig. 3), their contribution order was $4-\mathrm{CH}_{3}>4-\mathrm{N}\left(\mathrm{CH}_{3}\right)_{2}>-\mathrm{H}$. In addition, 2 aromatic heterocyclic compounds (3k, 3l) were also designed and synthesized. The pharmacological test revealed that compound 31 possessed good antidepressant activity at the $10 \mathrm{mg} / \mathrm{kg}$ dose level when compared with the control $(p<0.01)(\odot$ Fig. 3,4$)$.

As shown in $\bullet$ Fig. 5, immobility in the FST was significantly reduced after treatment with compounds $3 \mathrm{~d}, 3 \mathrm{~h}$ with better activities, similar to fluoxetine, indicating a significant antidepressant-like effect. The decrease in immobility time in the TST was similar to that seen in the FST. Compounds $3 \mathrm{~d}$ and $3 \mathrm{~h}$ showed good antidepressant activity and promoted a significant decrease in the immobility time at $10 \mathrm{mg} / \mathrm{kg}$ (control = $130.5 \pm 9.6$; $3 d=112.8 \pm 16.0 ; \quad 3 h=98.3 \pm 19.8 ;$ fluoxetine $=75.6 \pm 8.3)$. Both the FST and the TST are the accepted stress models of depression. The immobility has been shown to reflect a state of 'behavioral despair and variants' or 'failure to adapt to stress' [26]. The immobility displayed in both of these behavioural despair models has been hypothesized to reflect depressive disorders in human. There was a significant correlation between clinical potency and the potency of antidepressants in both models. Compounds $3 \mathrm{~d}$ and $3 \mathrm{~h}$ significantly produced antidepressantlike activity in both the FST and TST in mice, which indicates that compounds $3 \mathrm{~d}$ and $3 \mathrm{~h}$ possess some antidepressant effects.

Finally, 2 behavioural models were used to investigate the possible monoaminergic participation in the antidepressant activity. Compounds $3 \mathrm{~d}$ and $3 \mathrm{~h}$, as the most active compounds, were chosen for the behavioural tests. Compounds $3 \mathrm{~d}$ and $3 \mathrm{~h}$ significantly increased the cumulative number of head twitches ( $p<0.05$ vs. control) in the 5-HTP-induced mouse head-twitch test, whereas it enhanced the mouse lethality ( $p<0.05$ vs. control) induced by yohimbine. The results indicate that the serotonergic, but not the noradrenergic system, was involved in the antidepressant-like effect of compounds $3 \mathrm{~d}$ and $3 \mathrm{~h}$ ( $\bullet$ Table 1,2 ).

Several lines of evidence indicate that serotonergic, dopaminergic, and noradrenergic neurotransmissions are involved in the expression of an antidepressant-like effect in the behavioural despair models of depression [27]. Many antidepressant drugs exert their effects by modulating these neurotransmission systems $[28,29]$. The 5 -HTP-induced mouse head-twitch test is an 
Table 2 Effects of compound 3d, $3 \mathrm{~h}$ and clomipramine on yohimbine induced lethality in mice.

\begin{tabular}{|c|c|c|c|c|}
\hline \multirow[t]{2}{*}{ Compounds } & \multirow[t]{2}{*}{ Dose $(\mathrm{mg} / \mathrm{kg})$} & \multirow[t]{2}{*}{ yohimbine $(\mathrm{mg} / \mathrm{kg})$} & \multicolumn{2}{|c|}{ Lethality } \\
\hline & & & Total & Died \\
\hline $3 d$ & 30 & 20 & 10 & 4 \\
\hline $3 \mathrm{~h}$ & 30 & 20 & 10 & 3 \\
\hline $\begin{array}{l}\text { Clomi- } \\
\text { pramine }\end{array}$ & 30 & 20 & 10 & 8 \\
\hline Control & - & 20 & 10 & 2 \\
\hline
\end{tabular}

effective method to evaluate serotonergic effects of drugs in vivo [30]. It has been generally accepted that the number of head twitches represent the level of 5-hydroxytryptamine (5-HT) in the synapses. Yohimbine is an $a_{2}$-adrenergic released by its antagonistic action on the presynaptic $a_{2}$-adrenoceptor [31]. The yohimbine toxicity potentiation test is usually used for the evaluation of noradrenergic effect of antidepressants [32].

\section{Conclusions}

In conclusion, twelve 2,4-dihydroxychalcone compounds were synthesized and evaluated for their antidepressant activity using the FST and TST tests. 6 compounds showed antidepressant activity at a dose of $10 \mathrm{mg} / \mathrm{kg}$ i.p. Among the compounds, 3d and $3 \mathrm{~h}$ had the most antidepressant activity, and significantly reduced the duration of immobility times when compared with the control $(p<0.001)$ in the FST. Further studies are needed to reveal the mechanism of the antidepressant-like effect of compounds $3 \mathrm{~d}$ and $3 \mathrm{~h}$.

\section{Acknowledgments}

This work was supported by the National Natural Science Foundation of China (No. 30960458) and the Natural Science Foundation of Zhejiang Province of China (No. LY12C19005). This work was supported by Jilin Province Department of Education P.R. China ([2009] No. 13).

\section{Conflict of Interest}

We declare that we have no conflict of interest with respect to this study.

\section{References}

1 Meyer C. Depressive disorders were the fourth leading cause of global disease burden in the year 2000. Evid Based Ment Health 2004; 7 : 123-127

2 Lopez AD, Murray CC. The global burden of disease, 1990-2020. Nat Med 1998; 4: 1241-1243

3 Thase MS. Evaluating antidepressant therapies: remission as the optimal outcome. J Clin Psychiatry 2003; 64 (Suppl 13): 18-25

4 Thase ME, Corya SA, Osuntokun $O$ et al. A randomized, double-blind comparison of olanzapine/fluoxetine combination, olanzapine, and fluoxetine in treatment-resistant major depressive disorder. J Clin Psychiatry 2007; 68: 224-236

5 Hirschfeld RM. Efficacy of SSRIs and newer antidepressants in severe depression: comparison with TCAs. J Clin Psychiatry 1999; 60: 326-335
6 Go ML, Wu X, Liu XL. Chalcones: an update on cytotoxic and chemoprotective properties. Curr Med Chem 2005; 12: 481-499

7 Batovska D, Parushev St, Slavova A et al. study on the substituents effects of a series of synthetic chalcones against the yeast Candida albicans. Eur J Med Chem 2007; 42: 87-92

8 Lahtchev KL, Batovska DI, Parushev StP et al. Antifungal activity of chalconed: A mechanistic study using various yeast strains. Eur J Med Chem 2008; 43: 2220-2228

9 TrivediJC, Bariwal JB, Upadhyay KD et al. Improved and rapid synthesis of new coumarinyl chalcone derivatives and their antivira activity. Tetrahedron Lett 2007; 48: 8472-8474

10 Vogel S, Barbic M, Jürgenliemk $G$ et al. Synthesis, cytotoxicity, antioxidative and anti-inflammatory activity of chalcones and influence of A-ring modifications on the pharmacological effect. Eur J Med Chem 2010; 45: 2206-2213

11 Kimura Y, Baba K. Antitumor and antimetastatic activities of angelica keiskei roots, part 1: Isolation of an active substance, xanthoangelol. Int J Cancer 2003; 106: 429-437

12 Zhao DH, Sui X, QU YL et al. Synthesis and Studies on Antidepressant Effect of 5,7-Dihydroxyflavanone Derivatives. Asian J of Chem 2011; 23: $1129-1132$

13 Zhao DH, Zhang YZ, Zheng ZH. Synthesis and Studies on Antidepressant Effect of 2',4'-dihyoxylchalcone. Shi Zhen Medicine and Materia Medica Research 2010; 21: 1115-1116

14 Porsolt RD, Bertin A, Jalfre M. Behavioural despair in mice: a primary screening test for antidepressants. Arch Int Pharmacodyn Ther 1977; 229: $327-336$

15 Porsolt $R D$. Antidepressants: Neurochemical Behavioral and Clinical Perspectives. In: Enna SJ, Malick JB. Richelson E (eds.). Raven Press, New York: 1981; 129-139

16 Elhwuegi AS. Central monoamines and their role in major depression. Prog Neuropsychopharmacol Biol Psychiatry 2004; 28: 435-451

17 Millan MJ. The role of monamines in the actions of established and "novel" antidepressant agents: a critical review. Eur J Pharmacol 2004; 200: 371-384

18 Nishida J, Kawabata J. DPPH radical scavenging reaction of hydroxyand methoxychalcones. Biosci Biotechnol Biochem 2006; 70: 193-202

19 Sui X, Zhao DH, Qu YL et al. Synthesis and studies on antidepressant activity of 2',4',6'-trihydroxychalcone derivatives. Med Chem Res 2011; 21: 1290-1296

20 Guan LP, Yin XM, Quan HM et al. Synthesis of hydroxylated chalcones and related derivatives. Chinese J Org Chem 2004; 24: 1274-1277

21 Steru L, Chermat R, Thierry B et al. The tail suspension test: a new method for screening antidepressants in mice. Psychopharmacology 1985; 85: 367-370

22 Hanna MM, Eida NM, Georgea RF et al. Synthesis of some tropane derivatives of anticipated activity on the reuptake up norepinephrine and/or serotonin. Bioorg Med Chem 2007; 15: 7765-7772

23 Goodwin GM, Green AR, Johnson P. 5-HT2 receptor characteristics in frontal cortex and 5-HT2 receptor-mediated head-twitch behaviour following antidepressant treatment to mice. Br J Pharmacl 1984; 83: 235-242

24 Nishida J, Kawabata J. DPPH radical scavenging reaction of hydroxyand methoxychalcones. Biosci Biotechnol Biochem 2006; 70: 193-202

25 Zhao LM, Jin HS, Sun LP et al. Synthesis and evaluation of antiplatellet activity of trihydroxychalcone derivatives. Bioorg Med Chem Lett 2005; 15: 5027-5029

26 Bourin M, Chenu F, Ripoll $N$ et al. Aproposal of decision tree to screen putative antidepressants using forced swim and tail suspension tests. Behav Brain Res 2005; 164: 266-269

27 Petit-Demouliere B, Chenu F, Bourin M. Forced swimming test in mice: a review of antidepressant activity. Psychopharmacology (Berl.) 2005; 177: 245-255

28 Schechter $L E$, Ring $R H$, Beyer $C E$ et al. Innovative approaches for the development of antidepressant drugs: current and future strategies. NeuroRx 2005; 2: 590-611

29 Richelson E. The clinical relevance of antidepressant interaction with neurotransmitter transporters and teceptors. Psychopharmacol Bull 2002; 36: 133-150

30 Corne SJ, Pickering RW, Warner BT. A method for assessing the effects of drugs on the central actions of 5-hydroxytryoptamene. Br J Pharmacol Chemother 1963; 20: 106-120

31 Lapin IP. Adrenergic nonspecific potentiation of yohimbine toxicity in mice by antidepressants and related drugs and antiyohimbine action of antiadrenergic and serotonergic drugs. Psychopharmacology 1980; 70: $179-185$

32 Luo ZP. Beijing: People's Medical Publishing House, 2005 